\title{
9 \\ Does Moral Virtue Constitute a Benefit to the Agent?
}

\author{
BRAD HOOKER
}

\section{INTRODUCTION}

Something is instrumentally beneficial to someone if it is a means to some further thing that itself constitutes a benefit to that person. Being morally virtuous is often instrumentally beneficial to the agent. It can bring the agent pleasure and peace of mind and such social rewards as others' co-operation and respect. ${ }^{\mathrm{I}}$ But as my title indicates, this essay is about constitutive benefits rather than instrumental ones. Different theories of individual welfare-of what makes a person's life go well or badly for him or her-differ over what things constitute benefits to people. What do the main theories of individual welfare say about whether moral virtue constitutes a benefit to the agent?

Theories of individual welfare fall into three main categories: hedonism, the desire-fulfilment theory (sometimes called the preferencesatisfaction theory), and the list theory. ${ }^{2}$ Hedonism claims that how beneficial something is to us is entirely a matter of how much pleasure

${ }^{1}$ But a long-standing dispute exists over whether having moral dispositions always has enough instrumental benefit to the agent to outweigh the costs to him or her of developing or retaining those dispositions. For an excellent discussion of this issue, see G. SayreMcCord, 'Deception and Reasons to be Moral', American Philosophical Quarterly 26 (1989), I13-I22.

2 Though this way of dividing the theories is common, the terminology comes from D. Parfit, Reasons and Persons (Oxford, 1984), Appendix I, except that what I call the list theory he calls 'the Objective List Theory'. I have deviated from his terminology in order to inhibit the assumption that the list theory, which is a view about what constitutes individuals' welfare, is committed to an objectivist or realist view about the nature of prudential values. As I explain in 'Theories of Welfare, Theories of Good Reasons for Action, and Ontological Naturalism', Philosophical Papers 20 (199I), 25-36, the list theory of welfare is compatible with anti-realist metaphysical views (such as projectivism) and with expressivist views about the nature of evaluative judgement. 
(or reduction of pain) we get from it. The desire-fulfilment theory maintains that the best life for us in self-interested terms is whichever one involves the maximum fulfilment of desire. And the list theory maintains that how beneficial some things are to us is not just a matter of how much pleasure we get from them or of how much they fulfil our desires. In the next section I discuss what hedonism and the desirefulfilment theory say about whether being virtuous constitutes a benefit to the agent. I shall then turn to the list theory. What hedonism and the desire-fulfilment theory say about whether being virtuous constitutes a benefit to the agent is fairly straightforward. Figuring out what the list theory says about the matter is more difficult. Therefore, most of the essay will be on the list theory.

Being a virtuous person is a matter of having and acting on a set of character traits, or settled dispositions. ${ }^{3}$ Which dispositions? I would like to leave this somewhat open. But I will focus on other-regarding dispositions (such as dispositions to be just, trustworthy, generous, etc.). The traditional problem of reconciling virtue with self-interest focuses, of course, on other-regarding virtues. ${ }^{4}$

Someone might suggest that worrying about whether moral virtue benefits the agent is deeply confused, since being honest, fair, kind, etc. for the sake of benefits to oneself is not moral virtue. ${ }^{5}$ That may be true. But we can nevertheless be interested in whether having moral virtues constitutes a benefit to the morally virtuous person.

\section{HEDONISM AND DESIRE-FULFILMENT THEORY}

Many philosophers who have discussed the relation between self-interest and morality have been hedonists about welfare. According to hedonism,

3 See Aristotle, Nicomachean Ethics $(=N E)$ I $105^{\mathrm{a}} 30-3 \mathrm{I}$.

4 After all, the potential for conflict between self-regarding virtue and self-interest is fairly slight. In any event, my question is whether moral virtue constitutes a benefit to the agent. The focus on moral virtue leads to a focus on other-regarding virtue, since morality is (at least primarily) concerned with how one treats others-see T. Nagel, The View From Nowhere (New York, 1986), 197; B. Williams, Ethics and the Limits of Philosophy (Cambridge, Mass., I985), I2-I3; B. Gert, Morality (New York, 1988), 5; R. Brandt, 'Morality and its Critics', American Philosophical Quarterly 26 (I989), 89-100, p. 99; and Julia Driver's essay in the present volume.

${ }^{5}$ F. H. Bradley wrote, "what is clear at first sight is, that to take virtue as a mere means to an ulterior end is in direct antagonism to the voice of the moral consciousness' ('Why Should I Be Moral?', in his Ethical Studies, 2nd edn. (Oxford, I927), 58-84, p. 6I). See also H. A. Prichard, 'Does Moral Philosophy Rest on a Mistake?' and 'Moral Obligation', in his Moral Obligation (Oxford, I949), I-I7, 87-163; and N. Lemos, 'High-Minded Egoism and the Problem of Priggishness', Mind 93 (I984), 542-58. 
although being morally virtuous may be instrumentally beneficial to you in that it brings you pleasure, being morally virtuous is not in itself a self-interested good. Hedonists would say that your acting morally, say, refraining from cheating someone, brings you some benefit only if it brings you some pleasure. Being moral is not what constitutes the benefit to you; instead, the benefit to you is constituted by whatever pleasure you get as a result of your moral behaviour. Note this consequence: if the chief pleasure you get out of being morally virtuous comes from your thinking you are, then you might be better off not actually being morally virtuous but merely believing falsely that you are-because actually being morally virtuous can carry considerable costs.

Most philosophers today who are not hedonists about welfare accept the desire-fulfilment theory of welfare. The desire-fulfilment theory maintains that the best life for you in self-interested terms is the one involving the greatest fulfilment of the desires you have in that life. Such a theory takes into account the number of desires that get fulfilled, the relative importance to you of your various desires, and how long they last. ${ }^{6}$ But these and other complications can be ignored here. The main difference between the desire-fulfilment theory and hedonism comes out in cases in which you have a desire that is fulfilled without your getting any pleasure from this fact, because, for example, you do not know that it has been fulfilled. In such cases, the desire-fulfilment theory maintains that the fulfilment of that desire constitutes a benefit to you; hedonism maintains that it does not.

Proponents of the desire-fulfilment theory of welfare distinguish between desiring something as a means to some further thing and desiring something as an end in itself. A stock example of a desire for something as a means to some further thing is the desire to go to the dentist. In contrast, one's own pleasure is something typically desired for its own sake. And other things are desired in this way-for example, many people desire both personal autonomy and knowing the truth about important matters at least partly for their own sakes. Desire-fulfilment theorists couch their theory in terms of desires for ends-only fulfilment of these desires constitutes benefits to the agent. I thus have no need to refer to desires for things as means. So I shall use the term 'desires' to refer to desires for ends.

6 For a discussion of the intricacies of this kind of theory, see Parfit, Reasons and Persons, Appendix I. See also P. Bricker, 'Prudence', Journal of Philosophy 77 (1980), 381-40I; and J. Griffin, Well-being: Its Meaning, Measurement, and Moral Importance (Oxford, 1986), Part One. 
One version of the desire-fulfilment theory says the fulfilment of any desire of yours, even if that desire is based on faulty reasoning or mistaken beliefs, constitutes some benefit to you. A more restrictive version of the theory claims instead that something constitutes a benefit to you if but only if it fulfils your 'informed' desires, that is, desires that are not based on illogical reasoning or false empirical beliefs. Mark Overvold persuasively argues for further restrictions on which desires are to count in the assessment of someone's welfare: the only desires that should count are the agent's desires for things that involve the agent in some way. ${ }^{7}$ But many moral desires pass all these tests. Examples might be people's desires that they be kind, that they be fair, that they be honest, and, more generally, that they live a moral life. Holders of the desirefulfilment theory would conclude that the fulfilment of any of these moral desires constitutes a benefit to these people. So, on this view, being morally virtuous constitutes a benefit to the agent if but only if the agent has the relevant desires. We might say that, on this view, moral virtue contingently constitutes a benefit to the agent. ${ }^{8}$

Desire-fulfilment theorists would add, however, that the fulfilment of any moral desire will also constitute a loss to the agent if the fulfilment of that desire causes some other present or future desire of the agent's to go unfulfilled. This kind of loss might be greater than the benefit constituted by the fulfilment of the moral desire. When that is the case, and there are no relevant side-effects, the fulfilment of that moral desire is, on balance, against the agent's self-interest.

\section{THE LIST THEORY OF WELL-BEING}

The rest of this essay is about the other main theory of individual welfare, the list theory. ${ }^{9}$ The list theory holds that how beneficial some

${ }^{7}$ M. Overvold, 'Self-Interest and the Concept of Self-Sacrifice', Canadian Journal of Philosophy 10 (1980), 105-18. See also Parfit's discussion of what he calls 'the Success Theory' (Reasons and Persons, Appendix I). In my 'Overvold's Contribution to Philosophy', Journal of Philosophical Research 16 (1990/1), 333-44, I argue that Overvold's restriction should be glossed as proposing that the only desires that count are ones for

events or states of affairs in which the agent is an essential constituent.
8 Some desire theorists might be uncomfortable with any talk of being moral's constituting a benefit to the agent. They might say that, in so far as having moral dispositions has prudential value for someone, it has this prudential value not really because the dispositions are moral, but only because the person desires to have those dispositions.

${ }^{9}$ For some excellent defences of the list theory, see D. Brink, Moral Realism and the Foundations of Ethics (Cambridge, Mass., 1989), 22 I-36; T. M. Scanlon, 'Value, Desire, and Quality of Life', in M. Nussbaum and A. Sen (eds.), The Quality of Life (Oxford, 1993), 185-200. See also R. Nozick, The Examined Life (New York, 1989), especially ch. Io. 
things are to us is not merely a matter of how much pleasure they give us or of how much they fulfil our desires. Some of the things that might be listed as having this status as prudential goods are autonomy, ${ }^{10}$ friendship, knowledge of important matters, achievement, and perhaps the appreciation of beauty. List theorists can add that our pleasure also constitutes a benefit to us. "

We can distinguish between at least three general types of list theory. According to one type, certain things are good for me even if I do not desire them or get any pleasure from them (though pleasure itself is an additional good). According to the second type, a necessary condition of something's being beneficial to me is that I get pleasure from it, but how much pleasure I get from something is not the only factor in determining how beneficial to me the thing is. So, on this second view, playing push-pin and appreciating excellent poetry might be equally pleasant for me, but the latter is better because it involves appreciating beauty, while the former does not. The third type of list theory makes a connection with desire rather than pleasure. This type holds that a necessary condition of something's being beneficial to me is that I desire it, but how much or how long I desire it is not the only factor in determining how beneficial to me the thing is. On this third view, although I may desire push-pin as much as excellent poetry, poetry is nevertheless better. For the purposes of this paper, however, I can remain neutral on the question of which of these three general types of list theory is best. ${ }^{12}$

What is the relation of the list theory to perfectionism? Perfectionism is a sub-species of the list theory. Perfectionism differs from other kinds of list theory in claiming that we ascertain what gets on the list by

${ }^{10}$ For the best discussion of autonomy's place on a plausible list, see R. Crisp, 'Medical Negligence, Assault, Informed Consent, and Autonomy', Journal of Law and Society I7 (I990), 77-89, pp. 8I-4.

"One commentator suggested that I manifest a male bias by not listing marriage and children. Of course, marriage and children can be sources of friendship, pleasure, achievement, and knowledge. But do they have a place on the list apart from their connection with those other goods? I will not take sides on this matter here.

${ }^{12}$ But for useful discussion, see W. Frankena, Ethics, and edn. (Englewood Cliffs, NJ, 1973), 91; Parfit, Reasons and Persons, 502; and G. Trianosky, 'Rightly Ordered Appetites: How to Live Morally and Live Well', American Philosophical Quarterly 25 (1988), I-I 2, pp. 3-4. See also C. Korsgaard's discussion of the idea that getting pleasure out of something can be the condition of that thing's having value without the thing's being valuable merely as a means to pleasures: 'Two Distinctions in Goodness', Philosophical Review 92 (1983), 169-95, pp. 186-7. Especially clear and persuasive on all this is $R$. Crisp, 'Sidgwick and Self-Interest', Utilitas 2 (1990), 267-80, sections ii and ii. I will not venture into the vexed question of how Aristotle's view of a person's good relates to those above, but see R. Kraut, 'Two Conceptions of Happiness', Philosophical Review 88 (1979), I67-97, esp. pp. I70-7, I81. 
considering essential, distinctive, or characteristic human capacities or activities. That is, other kinds of list theory would reject the idea that your having or exercising $X$ constitutes a benefit to you if and only if $\mathrm{X}$ is an essential, distinctive, or characteristic human capacity or activity. These list theories would rely on some other way of coming up with a list, such as direct appeal to intuition about self-interested value, for example. I later offer my proposal for how to determine what we think should be on the list.

Some people might reject the particular list of goods I have mentioned because they think some other list is superior. Other people might reject the whole idea of a list theory because they think it a dangerous pretence. Although this essay is not about which of hedonism, the desire-fulfilment theory, and the list theory is the most plausible theory of well-being, I will indicate why a list theory is not so odious as to be beyond discussion.

Many people reject the list theory because they think it has outrageously paternalistic implications: they see looming the spectre of people's imposing 'the good life' on others. However, the list theory identifies autonomy as one of the prudential values. It might even go so far as to give overriding importance to autonomy. Therefore, the list theory itself might prohibit what we intuitively think of as objectionable paternalism. ${ }^{13}$ Furthermore, even if autonomy were not one of the things on the list, paternalism would be in the offing only if morality requires or permits forcing things on people that they do not want. But morality might not require or permit this. So even if the list theory did not itself have the resources to block objectionable paternalism, the list theory could be combined with a moral theory providing the necessary prohibitions.

So, do the most plausible versions of the list theory hold that moral virtue constitutes a benefit to the agent? In the next section, I shall consider the best arguments I can think of for concluding that moral virtue does constitute a benefit to the agent.

\section{THREE ARGUMENTS FOR THINKING THAT VIRTUE CONSTITUTES A BENEFIT TO THE AGENT} Here is one such argument. Knowledge of important matters is on the list. What is right and what is wrong are important matters. Therefore,

${ }^{13}$ This point is made in a number of places (e.g., J. Finnis, Fundamentals of Ethics

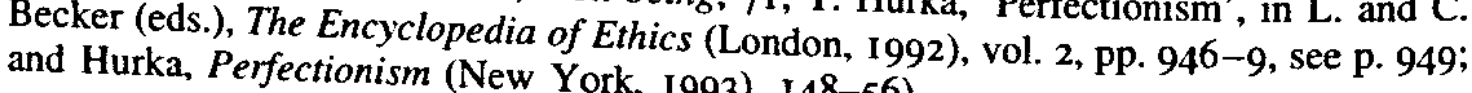


one of the things on the list is knowing what is right and what is wrong. Furthermore, knowing right and wrong brings with it moral motivation. Hence, moral virtue is a necessary concomitant of something on the list. Let us call this the argument from knowledge.

Obviously, many things about this argument are controversial. First, whether there really is moral knowledge is controversial. Second, it is controversial whether, even if there is moral knowledge, moral knowledge necessarily brings with it moral motivation. ${ }^{14}$ Third, it is controversial whether, even if there is moral knowledge and there is a necessary ('internal') connection between it and moral motivation, this moral motivation must be sufficient to qualify one as morally virtuous. ${ }^{15}$ For some hold that, although anyone who knows that certain acts would be morally wrong must have some motivation to avoid these acts, this motivation might not be particularly strong. Being morally virtuous, however, involves having certain very strong (if not overriding) motivations. Therefore, if moral knowledge does not necessarily bring with it strong moral motivation, one can have moral knowledge without being morally virtuous. In fact, the only people who would accept the argument from knowledge are those who think that there is moral knowledge and that it necessarily brings with it moral motivations that are sufficiently strong to qualify a person as virtuous.

I turn now to a more promising argument. One premiss of this argument is that the most plausible versions of the list theory will have achievement on the list. The other premiss is that living a truly moral life is an achievement. From these premisses it follows that moral virtue gets on the list because being morally virtuous is a kind of achievement. Call this the argument from achievement. ${ }^{16}$

Why think that living a moral life is a significant achievement? Given

14 Some representative examples of philosophers who deny that there is a necessary connection between moral judgement and motivation are W. Frankena, 'Obligation and Motivation in Recent Moral Philosophy', in A. I. Melden (ed.), Essays in Moral Philosophy (Seattle, 1958), 40-8I; D. A. J. Richards, A Theory of Reasons for Action (Oxford, 1971); and Brink, Moral Realism and the Foundations of Ethics, ch. 3.

15 Endorsements of what we might call 'internalist cognitivism' about moral judgements appear in H. Sidgwick, The Methods of Ethics, $7^{\text {th }}$ edn. (London, 1907), 34; J. McDowell, 'Non-Cognitivism and Rule-Following', in S. Holtzman and C. Leich (eds.), Wittgenstein: To Follow a Rule (Oxford, I981), 141-62, pp. 154-5, 161, nn. 19 and 20; T. Nagel, The Possibility of Altruism (Oxford, 1970), 8-9, and The View From Nowhere, 138-52, esp. pp. I39, I44, I48, 149; D. McNaughton, Moral Vision (Oxford, 1988), 4650. See also S. Scheffler, Human Morality (New York, 1992), chs. 4-5.

${ }^{16}$ For hints of the argument from achievement, see Griffin, Well-Being, 69-70, I32. Frankena presents the following similar but more general argument: other things being equal, one's life goes better to the extent that it involves excellences; being moral is a kind of excellence; therefore, moral virtue does, other things being equal, benefit the agent 
that writing a great book is an achievement that makes someone's life go better in self-interested terms, why wouldn't righting a great wrong be one too? Or consider the case of someone who succeeds in rescuing many innocent people from a genocidal army. Indeed, living a moral life even in a less heroic, more humdrum fashion is quite an achievement. ${ }^{17}$ So, given that two people have led lives with the same amount of non-moral achievement, but one has been moral and the other has not, the moral one's life has contained more achievement overall than the other's has. All else being equal, the life involving greater overall achievement (in this example, the moral person's) does seem superior from the point of view of the list theory.

A note of caution: the conclusion just reached was not that moral virtue is always more beneficial to the agent than his or her other alternatives. Being moral is only one kind of achievement. Achievement is only one of the goods on the list. Thus, even if moral virtue does constitute $a$ benefit to the agent, there may be cases in which moral virtue brings such large losses in terms of the other things on the list that the greatest net benefit for the agent lies in not being moral. Such cases, I believe, are common.

Moreover, what of success in immoral schemes? Are they also achievements that constitute benefits to agents? Consider the career of the manipulative rake who achieved the status of being the best seducer in eighteenth century Paris. Imagine that, although he made a game of breaking hearts and disrupting lives, no one ever got back at him because of the overriding need to keep the nature of his predatory activity (seduction) secret. I just do not know what to make of the idea that agents' immoral achievements constitute benefits to them. ${ }^{18}$

Even if we reject that idea, we are left with the conclusion that moral virtue is only one kind of achievement and achievement is only one of the goods on the list. We might wonder whether we could not have (Ethics, 9I, 93-4). But the argument from achievement seems to me more persuasive
than the argument from excellence.

17 See Susan Wolf's probing account of what being a moral saint would be like: 'Moral Saints', Journal of Philosophy 79 (1982), 419-39. She pictures the moral saint as being 'dominated by a commitment to improving the welfare of others or of society as a whole' (p. 420). One difference between her paper and this essay is that I am concerned mainly morality. I presume this falls well short of being dominated by everyday, common-sense

ing the welfare of others or of society as a whole.
18 For an impressive defence of the idea that immitment to improv-

tions to aggregate good, see Hurka, Perfectionism, I9-20, and index s.v 'Perfectionism, Moralistic'. 
reached a more cheering conclusion. More specifically, while not forgetting that being morally virtuous is a kind of achievement, we might wonder whether moral virtue has a less subordinate, less attenuated place on the list. We might ask whether it also has a place on the list at the same level as knowledge, friendship, pleasure, and achievement. Does moral virtue stand shoulder to shoulder with these other values? Let me mark the status on the list that knowledge, friendship, pleasure, achievement, and perhaps the appreciation of beauty have by referring to them as fundamental categories of prudential value. So another way of asking whether moral virtue has a place on the list at the same level as knowledge, friendship, pleasure, and achievement is to ask whether moral virtue is also a fundamental category of prudential value. I take up this question in the next section.

\section{THE SYMPATHY TEST}

How sorry we feel for someone is influenced by how badly from the point of view of his own good we think that person's life has gone, that is, by whether we think his life has lacked important prudential goods. Consider someone whose life has been predominantly painful and contained little knowledge or achievement or appreciation of beauty, though it has involved some deep, long-lasting friendships. We would feel sorry for the person who had this life, because of the prudential goods his life lacked. But our sorrow for the person would not be as great as it would be if his life had not contained friendship. That is, if his life had not contained friendship, we would feel even sorrier for him. Or if two people's lives have contained the same amounts of pleasure, knowledge, and autonomy, but one has contained significantly more achievement than the other, we feel sorrier for the person whose life has contained less achievement.

We could try applying this line of thought to the question of whether we think moral virtue is a fundamental category of prudential value. Consider two people who lead sad and wretched lives. Suppose that one of these two people is morally virtuous, and that the other is not. Let us use the name 'Upright' for the one who is morally virtuous, and the name 'Unscrupulous' for the one who is not. We would not feel sorrier for Unscrupulous. This suggests that we do not really believe that moral virtue has the same status on the list as pleasure, knowledge, achievement, 
and friendship. I will refer to this argument as the argument from lack of sympathy. ${ }^{19}$

The argument is inadequate as it stands. For one of its premisses is this: If (I) two people are as much alike as possible except that one's life contains something which the other's does not and (2) we do not feel sorrier for the one whose life lacks this thing, then the explanation is that we do not really think this thing is one of the fundamental categories of prudential value. This premiss, however, needs amendment. But I will argue that, with this premiss amended, the argument will have considerable force.

Admittedly, even after the amendments to that premiss are added, the argument holds out no hope of convincing either people who do feel sorrier for Unscrupulous or people who confidently believe that moral virtue is on the list as a fundamental category of prudential value. Thus the argument from lack of sympathy is addressed only to those of us who (a) do not know what we think about whether moral virtue is a fundamental category of prudential value and (b) do not feel sorry for the immoralist. Obviously, I would not be discussing this argument if I did not think this is a large group. The question, then, for those of us in this group is whether the reason we lack sympathy for Unscrupulous is that we do not believe moral virtue is a fundamental category of prudential value (though we might not initially realize this).

The argument from lack of sympathy presupposes that we can believe something without knowing that we believe it. And it presupposes that this holds true for evaluative beliefs as well as for non-evaluative ones. It further presupposes that these beliefs can sometimes be brought to light by reflection on our sentiments. These presuppositions seem justified. Suppose that I am initially unsure whether a given kind of act is morally wrong. Then I realize that I would not only resent someone's doing that kind of act to me but also feel the resentment justified. One possible explanation of my having these sentiments is that I really think that kind of act is wrong. So, my becoming aware that I would have these sentiments might show me a moral belief I did not know I had.

I shall now consider objections to the argument from lack of sympathy. These objections all have the same structure. The argument from lack of sympathy depends on the idea that the explanation of our not feeling I9 See A. Sen, 'Plural Utility', Proceedings of the Aristotelian Society 8I (1980/I),
I93-215, p. 203. 
sorrier for Unscrupulous is that we really think moral virtue is not one of the fundamental categories of prudential value. The objections I consider suggest that there is some other explanation, and thus that we might not feel sorrier for the immoral Unscrupulous than for the moral Upright even though we think that Unscrupulous's life does indeed go worse.

For example, the following explanation may be offered of why we do not feel sorrier for Unscrupulous. Feeling sorry for someone essentially involves sharing in or taking on (in some sense) that other person's unpleasant feelings or mental states. Thus, what explains our not feeling sorrier for Unscrupulous than for Upright is that the amount of unpleasantness Upright and Unscrupulous experience is the same.

But the analysis of feeling sorry for someone that is presupposed by this objection is too narrow. It is not true that whenever I feel sorry for someone I am sharing in, or taking on in some sense, that other person's feelings or mental states. Nor is it true that I can feel sorry only for those people who are having (or have had or will have) unpleasant mental states. To take a familiar example, suppose that Laura's husband is having affairs in spite of his solemn promise to her that he would not do this and in spite of her extremely strong desire that he not do it. Suppose he is so adept at orchestrating matters that she will never in any way be aware of his affairs. I may feel sorry for her even though I am completely convinced his affairs will not cause her to have less pleasant mental states. Given this case as I have set it out, what would be eliciting my sympathy for her could not be thoughts about unpleasant mental states she will have experienced. It would instead be the thought that she is deceived about a central aspect of her life. Likewise, how sorry we feel for Upright or for Unscrupulous in our test case need not be determined solely by how much unpleasantness they suffer.

Someone might now object that we do feel sorry for Unscrupulous on account of Unscrupulous's missing out on the prudential good of being moral, and that the reason we do not feel sorrier for Unscrupulous than for Upright is that our sympathy for Unscrupulous is counterbalanced by our sympathy for Upright. And the reason we feel sorry for Upright is that Upright is not getting more prudential goods than Unscrupulous, which is an injustice to Upright, given that Upright has been moral and Unscrupulous has not.

This objection can also be answered. We just need to add further stipulations about Upright and Unscrupulous. Suppose Upright and 
Unscrupulous have lives maximally full of (exactly equal amounts of) pleasure. Upright's life contains some moral pleasure ${ }^{20}$ unavailable to any immoral person, such as Unscrupulous; and Unscrupulous's life has some pleasures unavailable to any morally good person, such as Upright. Suppose also that both Unscrupulous and Upright have lives maximally full of (exactly the same amounts of) knowledge of important matters, friendship, ${ }^{21}$ autonomy, and the appreciation of beauty. And let us suppose their lives are full of (exactly the same amounts of) overall achievement (Upright's achievement of being morally virtuous is offset by the non-moral achievements of Unscrupulous). They thus have had lives full of exactly the same amount of each of the list's goods-with the disputed exception of having led a morally virtuous life. Now, since Upright has a life filled with all the goods one could hope for, it cannot be the case that she has been harmed or disadvantaged by the injustice to her of Unscrupulous's getting all the same goods without having to be virtuous. Since Upright lacks nothing, how can we feel sorry for her? And if we cannot feel sorry for Upright, then the objection we are considering is a non-starter.

Someone might now object that the reason we do not feel sorrier for Unscrupulous is merely that we do not feel at all sorry for someone whose life has been as rich as Unscrupulous's. After all, we have only so much sympathy to go around. And all of it is naturally directed at people much worse off than Unscrupulous.

This objection can be circumvented. Assume Unscrupulous lives in a wonderfully fortunate world in which every other individual's life is at least as good in self-interested terms as Unscrupulous's. No one in Unscrupulous's world is a better candidate for our sympathy. So, if we still don't feel sorry for Unscrupulous, this cannot be because our sympathy is used up on other people.

Another possible objection is that the real reason we do not feel sorry for Unscrupulous is that we do not feel sorry for people who miss out

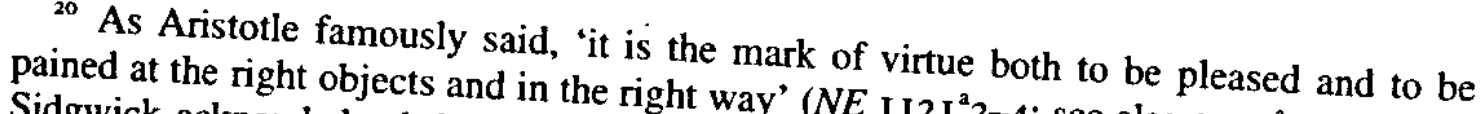
Sidgwick acknowledged that 'the right way' ( $N E$ I I 2 I $^{2} 3-4$; see also $1099^{2} 7-2 \mathrm{I}$ ). And to the non-moral man when he at first attempts isual inclination to duty is disagreeable

a deep and strong delight' (Methods of Ethics, I 50).
${ }_{21}$ It would be absurd to the truly virtuous man

not have friends: has no pirate or that an immoral person such as Unscrupulous could ship with someone involves caring about her had friends? To be sure, having a friendUnscrupulous must have some concem for the wer welfare. So in order to have friendship But this on its own is far too little to qualify hifare of some other people (his friends).
} 
on some prudential good through their own fault. If I repeatedly pass up opportunities to obtain knowledge and to develop friendships, then the fact that I live an ignorant and friendless life is no reason to feel sorry for me. Likewise, the fact that Unscrupulous did not lead a moral life is no reason to feel sorry for Unscrupulous, since he missed out on the benefit through his own fault.

There are two good answers to this objection. One is that we can have sympathy for someone even while we recognize that his predicament is his own fault. Fault does not always shut off sympathy. Sometimes we recognize that people are to blame for, say, ruining their lives, and yet we simultaneously feel sorry for them because of what they have brought on themselves. For example, we might blame Jack for being so imprudent as to marry (or divorce) Jill, but nevertheless feel sorry for him. Or we might blame the people of a country for being so gullible and short-sighted as to elect their present ruler, but still feel sorry for them. Now, given that in some cases fault and blame do not preclude sympathy, we should demand some explanation of why sympathy is absent in the case of our reactions to Unscrupulous.

The other good answer to the objection that we do not feel sorry for Unscrupulous because he is at fault is as follows. Suppose Unscrupulous grew up with no exposure to the influences that typically form moral dispositions in people (e.g. morally good role-models). Suppose that anyone with Unscrupulous's upbringing would turn out to lack moral dispositions. It is then hard to think that Unscrupulous's turning out as he did is his fault. And if Unscrupulous's turning out to lack moral virtues is not his fault, our not feeling sorry for Unscrupulous cannot be explained by reference to the matter of fault.

It might now be said that we cannot help but feel contempt for Unscrupulous, and that this contempt precludes whatever feelings of sorrow we might have for him. I doubt, however, we always feel contempt for people who are not moral. Moreover, contempt does not always shut off sympathy. There are contemptible characters in literature for whom we manage to feel some sympathy - think of some of the characters in Shakespeare's tragedies (Edmund in King Lear, for example, or Richard III). Closer to home, many of us manage to have simultaneous feelings of contempt and sympathy for ourselves. So the fact that contempt does not always preclude sympathy presents us with this question: Why think that what keeps us from feeling sympathy for Unscrupulous is contempt, rather than the belief that Unscrupulous is not worse off in self-interested terms than Upright? 
Someone might now say that the right explanation of our not feeling sorry for Unscrupulous is that we have some other negative feeling toward immoralists, such as indignation. ${ }^{22}$ Well, does indignation toward someone always preclude sympathy for him? If it does not, then we are owed an explanation of why it does so in the case of Unscrupulous. Admittedly, feeling sympathy for people at the same time as one feels indignation towards them may be rare. But it happens sometimes. Some of us felt at least a little sorry for Richard Nixon when he had to leave office (because of the humiliation, etc.) even though we at the same time thought he richly deserved moral censure and felt indignant toward him for what he had done. Thus, since indignation does not always preclude sympathy, I see no reason to think that the best explanation of what keeps us from feeling sorrow for Unscrupulous is
our indignation toward him.

Where does all this leave us? Unscrupulous and Upright have exactly the same amount of all the values on the list, with the disputed exception of moral virtue. They even have the same level of achievement, because Unscrupulous has some extra non-moral achievements compensating pulous than for Upright, one possible explanation of this is that we do not really believe Unscrupulous's life has gone worse in self-interested terms than Upright's. I have discussed a number of other possible explanations. Some of these explanations I have rejected. The rest I have undercut by designing the situation so that none of them will work. We
are left, I think, with two possible alternative conclusions.

If we still do not feel sympathy for Unscrupulous even with the situation designed so as to preclude the other possible explanations, we might conclude that the best explanation of our lack of sympathy for Unscrupulous is that we do not think Unscrupulous's life has gone worse in selfinterested terms. If we do not think Unscrupulous's life has gone worse in self-interested terms, then we must think that Unscrupulous's lacking the moral virtue that Upright has does not make Upright's life go better in virtue delf-interested terms. In other words, we apparently really believe moral achievement.

The other possible conclusion is that the argument from lack of sympathy breaks down. I have had to stipulate many conditions, some quite far-fetched, in order to prevent explanations other than the explanation

${ }^{22}$ This objection comes from Alan Goldman. 
that we do not really believe Unscrupulous's life has been worse in self-interested terms. As these stipulations mount up, so wanes our ability to decide whether we feel sorry for Unscrupulous. It may wane so far that our thinking about whether we would feel sorry for him fails to deliver any result.

Which of these alternative conclusions is most plausible? I tentatively accept the conclusion that the argument from lack of sympathy shows that moral virtue has no place on the list other than as a subcategory of achievement. Admittedly, my favouring this conclusion might be partly motivated by the suspicion that thinking about what we would feel sorry for someone for lacking is our best hope as a method of figuring out what we think are the fundamental categories of prudential value. If this method cannot help, I do not know where to turn. ${ }^{23}$

${ }^{23}$ For helpful comments on earlier drafts of this paper, I am grateful to Charlotte Brown, Robert Ginsberg, Alan Goldman, James Griffin, John Heil, Thomas Hurka, Rosalind Hursthouse, Martha Klein, Penelope Mackie, Al Mele, Mark Nelson, Ingmar Persson, John Robertson, Eldon Soifer, and Gabriele Taylor. I am especially grateful to John Bogart, Roger Crisp, Andrew Moore, Mark Overvold, and Peter Vallentyne, each of whom commented on more than one draft. Work on an earlier version was completed with the help of a Grant-in-Aid from Virginia Commonwealth University. Ancestors of the paper were presented at meetings of the Pacific Division of the American Philosophical Association, the Southern Society for Philosophy and Psychology, and Oxford University's Wolfson Society. 